\title{
ATHEROGENIC IMPACT OF HOMOCYSTEINE: CAN HMG-CoA REDUCTASE INHIBITORS ADDITIONALLY INFLUENCE HYPERHOMOCYSTEINAEMIA?
}

Tamara Nikolic ${ }^{1}$, Ivan Srejovic ${ }^{2}$, Isidora Stojic ${ }^{1}$, Jovana Jeremic ${ }^{1}$, Marko Folic ${ }^{1}$, Stevan Matic ${ }^{3}$, Milena Rakocevic ${ }^{3}$, Snezana Jancic ${ }^{3}$, Biljana Jakovljevic ${ }^{4}$, Radmila Obrenovic ${ }^{5}$, Dusan Djuric ${ }^{6}$ and Vladimir Zivkovic ${ }^{2}$ ${ }^{1}$ Department of Pharmacy, University of Kragujevac, Faculty of Medical Sciences, Kragujevac, Serbia ${ }^{2}$ Department of Physiology, University of Kragujevac, Faculty of Medical Sciences, Kragujevac, Serbia ${ }^{3}$ Department of Pathology, University of Kragujevac, Faculty of Medical Sciences, Kragujevac, Serbia ${ }^{4}$ Medical College of Applied Sciences, Belgrade, Serbia

5Institute for Medical Biochemistry, Clinical Centre of Serbia, Belgrade, Serbia

${ }^{6}$ Faculty of Medicine, Institute of Medical Physiology “Richard Burian”, University of Belgrade, Belgrade, Serbia

\author{
ATEROGENI POTENCIJAL HOMOCISTEINA: DA LI INHIBITORI HMG-CoA \\ REDUKTAZE MOGU UTICATI I NA HIPERHOMOCISTEINEMIJU?

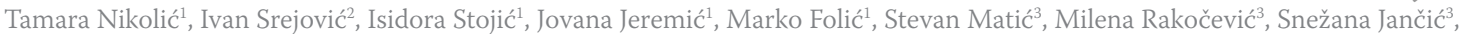 \\ Biljana Jakovljević, Radmila Obrenović , Dušan Đurić $^{6}$ i Vladimir Živkovićc ${ }^{*}$ \\ ${ }^{1}$ Katedra za farmaciju, Univerzitet u Kragujevcu, Fakultet medicinskih nauka, Kragujevac, Srbija \\ ${ }^{2}$ Katedra za fiziologiju, Univerzitet u Kragujevcu, Fakultet medicinskih nauka, Kragujevac, Srbija \\ ${ }^{3}$ Katedra za patologiju, Univerzitet u Kragujevcu, Fakultet medicinskih nauka, Kragujevac, Srbija \\ ${ }^{4}$ Visoka zdravstvena škola strukovnih studija, Beograd, Srbija \\ ${ }^{5}$ Institut za medicinsku biohemiju, Klinički Centar Srbije, Beograd, Srbija \\ ${ }^{6}$ Medicinski fakultet, Institut za medicinsku fiziologiju "Rihard Burijan, Univerzitet u Beogradu, Beograd, Srbija
}

Received / Primljen: 17. 10. 2017.

Accepted / Prihvaćen: 23. 10. 2017.

\section{ABSTRACT}

The strong association among the risk of coronary artery diseases (CAD), high levels of $L D L-C$ and low levels of $H D L-$ $C$ is well established. Hyperhomocysteinaemia (HHcy) is an independent risk factor for cardiovascular disease (CVD) and causes endothelial dysfunction, a hallmark of atherosclerosis. In this study, we ascertained the influence of statins on the atherogenic index, as an indicator and a significant adjunct for predicting atherosclerosis in hyperhomocysteinaemic male Wistar albino rats. For 4 weeks, the animals were fed with one of the following diets (Mucedola SRL., Milan, Italy): standard rodent chow; a diet enriched in methionine with no deficiency in $B$ vitamins or a diet enriched in methionine and deficient in $B$ vitamins. The animals were simultaneously exposed to a pharmacology treatment with atorvastatin at dose of $3 \mathrm{mg} / \mathrm{kg} /$ day i.p. or simvastatin, at dose of 5 $m g / k g /$ day i.p. We measured weight gain, food intake, and FER and determined the concentrations of biochemical parameters of dyslipidaemia (TC, TGs, LDL-C, VLDL-C, and $H D L-C), A I$, and CRR. A histopathological examination was conducted on portions of the right and left liver lobes from each animal. A connection between Hhcy and dyslipidaemia was indicated by the findings of biochemical and histological analyses, suggesting that Hhcy was a pro-atherogenic state. An improvement in the lipid profile along with a decrease in the atherogenic index by statins suggests that atorvastatin and simvastatin could be useful antiatherogenic agents, with protective activities during hyperhomocysteinaemia.

Keywords: atherogenic index, hyperhomocysteinaemia, liver, HMG-CoA reductase inhibitors

\section{SAŽETAK}

Izmedu rizika za nastanak koronarnih arterijskih bolesti (CAD), visokih nivoa LDL-C i niskih nivoa HDL-C je utvrdena jaka povezanost. Hiperhomocisteinemija (HHcy) je nezavistan faktor rizika za kardiovaskularne bolesti (CVD), uzrokuje endotelnu disfunkciju kao obelezje ateroskleroze. U ovoj studiji, utvrdićemo uticaj statina na aterogeni indeks mužjaka pacova Vistar albino soja sa hiperhomocisteinemojom, kao važnog indikatora i značajnog činioca u prognozi ateroskleroze. Životinje su hranjene sa jednom od sledećih dijeta tokom četiri nedelje (Mucedola SRL., Milan, Italy): standardnom hranom za pacove, hipermetioninskom dijetom bez deficita $B$ vitamina ili hipermetioninskom dijetom sa deficitom B vitamina. U isto vreme, životinje su bile izložene farmakološkom tretmanu atorvastatinom u dozi od 3 $\mathrm{mg} / \mathrm{kg} /$ dan i.p. ili simvastatinom u dozi od $5 \mathrm{mg} / \mathrm{kg} /$ dan i.p. Merili smo stopu prirasta telesne mase, unos hrane, FER $i$ određivali koncentracije biohemijskih parametara dislipidemije (TC, TGs, LDL-C, VLDL-C, HDL-C), AI, CRR. Histolopatološka istraživanja sprovedena su na uzorcima desnog $i$ levog lobusa jetre svake životinje. Povezanost Hhcy i dislipidemije je potvrđena biohemijskim $i$ histološkim analizama u našem istraživanju, navodeći na činjenicu da je Hhcy pro-aterogeno stanje. Poboljšanje lipidnog profila zajedno sa smanjenjem aterogenog indeksa usled upotrebe statina, navodi na zaključak da atorvastatin i simvastatin mogu biti upotrebljeni kao antiaterogeni agensi sa protektivnim delovanjem u toku hipehomocisteinemije.

Ključne reči: aterogeni indeks, hiperhomocisteinemija, jetra, inhibitori HMG-CoA reduktaze
UDK: 616-008.9:577.122.3, 616.13-004.6-02 Ser J Exp Clin Res 2019; 20 (2): 37-46 DOI: 10.1515/SJECR-2017-0055 Faculty of Medical Sciences, University of Kragujevac, Svetozara Markovica Str.69, 34000 Kragujevac, Serbia; Phone: +38134306800, E-mail: vladimirziv@gmail.com 


\section{INTRODUCTION}

A lipid profile consists of a group of biochemical tests often used in predicting, diagnosing and treating lipidrelated disorders including atherosclerosis. Generally, hyperlipidaemias are of interest to the physician in the context of risk factors for ischaemic heart disease (IHD) and peripheral vascular disease. The first step in the diagnosis of hyper- and hypolipoproteinaemias is to define the lipoprotein pattern by a chemical analysis of plasma lipids and lipoproteins. Abundant evidence has accumulated relating the concentrations of lipids (total cholesterol and triglycerides) and their associated blood transporting lipoproteins (HDL-C, LDL-C, and VLDL-C) with the occurrence of atherosclerosis in general and coronary artery disease (CAD) in particular (1-3).

The strong association among the risk of coronary artery diseases (CAD), high levels of LDL-C and low levels of HDL-C has been well established. However, the enormous contribution of triglycerides (TGs) to cardiovascular risk has been underestimated, especially in our environment (4). Indeed, high levels have been associated with an increased incidence of CAD and an increased population of small dense LDL-C particles $(5,6)$. Many studies have evaluated the relationship between TGs and HDL-C, and it has been shown that the ratio of TGs to HDL-C is a strong predictor of myocardial infarction. Universally, the atherogenic index of plasma (AIP), calculated as the log (TG/ HDL-C), is used by some practitioners as a significant predictor of atherosclerosis (7-9).

On the other hand, homocysteine (Hcy) is a sulfurcontaining amino acid, and the metabolism of Hcy is influenced by folic acid and vitamin $B_{12}$ deficiencies, which lead to high Hcy levels in the blood (10). In 1969, McCully made initial observations linking plasma Hcy concentrations and arteriosclerotic vascular disease (11). Hyperhomocysteinaemia (HHcy) has been associated with an increased risk of venous thrombosis (11), myocardial infarction (12), peripheral vascular disease (12), and coronary artery disease (13). Many subsequent studies have shown that high Hcy levels may present a risk factor for atherosclerosis. Hyperhomocysteinaemia (HHcy) is an independent risk factor for cardiovascular disease (CVD) and causes endothelial dysfunction, a hallmark of atherosclerosis (14). The mechanisms of hyperhomocysteinaemia (HHcy) that promote atherosclerosis are seldom explored and always indefinite. Possible mechanisms for the association between homocysteine and atherosclerosis include stimulation of smooth muscle cell growth, reduction in endothelial cell growth and endothelial cell relaxation, and decreased synthesis of high-density lipoproteins (12-15).

One possible therapeutic agent could be an inhibitor of 3-hydroxy-3-methylglutaryl coenzyme A (HMG-CoA) reductase, which is known as a statin. Several large trials published recently years have clearly shown that treatment with statins reduces coronary heart disease morbidity and mortality rates, and the beneficial effects manifest sooner than expected. Statin treatment affects variables such as endothelial function, cellular immunity, lipoprotein oxidation, rheological factors, and stabilization of atherosclerotic plaque (16).

In this study, we ascertained the clinical effects of statins on the atherogenic index, as an indicator and a significant adjunct for predicting atherosclerosis in hyperhomocysteinaemic male Wistar albino rats.

\section{MATERIAL AND METHODS}

\section{Chemicals}

All the reagents and substances were purchased from Sigma-Aldrich (Sigma-Aldrich Chemie $\mathrm{GmbH}$, Germany), including Atorvastatin calcium salt trihydrate $\geq 98 \%\left(\mathrm{C}_{33} \mathrm{H}_{34} \mathrm{FN}_{2} \mathrm{O}_{5} \times 0.5 \mathrm{Ca} \times 1.5 \mathrm{H}_{2} \mathrm{O}\right) \mathrm{MW}: 604.69$, (product number: PZ0001-25MG) and Simvastatin $\geq 97 \%$ (C25H38O5), MW: 418.35, (product number: S619625MG). All the food for the animals was purchased from Mucedola Corporation (Milan, Italy).

\section{Ethical Approval}

All the research procedures were carried out in accordance with European Directive for the welfare of laboratory animals No: 2010/63/EU and the principles of Good Laboratory Practice (GLP). The protocol for the current study was approved by the Ethics committee for experimental animal wellbeing of the Faculty of Medical Sciences of the University of Kragujevac, Serbia (No: 01-11794).

\section{Experimental design}

The animals were acclimatized for two weeks in the animal house at the Faculty of Medical Sciences in Kragujevac before dietary manipulation. Two rats were housed per wire floored cage in an air-conditioned room $(22 \pm$ $2^{\circ} \mathrm{C}$ ), with $12 \mathrm{~h} \mathrm{light/dark}$ cycles and had free access to standard or special laboratory chow diet and water ad libitum. The study was conducted on adult male Wistar albino rats ( $\mathrm{n}=72$; 4 weeks old), in which HHcy was achieved by dietary manipulation. For 4 weeks, the animals were fed with one of the following diets (Mucedola SRL., Milan, Italy): standard rodent chow; a diet enriched in methionine with no deficiency in B vitamins (folic acid, $\mathrm{B}_{6}$ and $\mathrm{B}_{12}$ ) or a diet enriched in methionine and deficient in B vitamins (folic acid, $B_{6}$ and $B_{12}$ ) (Table 1 ). At the same time, the animals were exposed to a pharmacology treatment with atorvastatin at a dose of $3 \mathrm{mg} / \mathrm{kg} /$ day i.p. or simvastatin at a dose of $5 \mathrm{mg} / \mathrm{kg} / \mathrm{day} i$.. at the same time every day, according to the equivalent therapeutic doses of these statins. The animals were divided into nine (9) different groups as follows: 
1. Animals fed with standard rodent chow without the administration of statins (vehicle);

2. Animals fed with a diet enriched in methionine with no deficiency in $\mathrm{B}$ vitamins (folic acid, $\mathrm{B}_{6}$ and $\mathrm{B}_{12}$ ) without the administration of statins (mild Hhcy);

3. Animals fed with a diet enriched in methionine and deficient in $\mathrm{B}$ vitamins (folic acid, $\mathrm{B}_{6}$ and $\mathrm{B}_{12}$ ) without the administration of statins (severe Hhcy);

4. Animals fed with standard rodent chow with the administration of atorvastatin, at a dose of $3 \mathrm{mg} / \mathrm{kg} /$ day i.p. (atorvastatin);

5. Animals fed with standard rodent chow with the administration of simvastatin, at a dose of $5 \mathrm{mg} / \mathrm{kg} /$ day i.p. (simvastatin);

6. Animals fed with a diet enriched in methionine with no deficiency in $B$ vitamins (folic acid, $B_{6}$ and $B_{12}$ ) with the administration of atorvastatin, at a dose of $3 \mathrm{mg} / \mathrm{kg} /$ day i.p. (ato+mild Hhcy);

7. Animals fed with a diet enriched in methionine with no deficiency in $B$ vitamins (folic acid, $B_{6}$ and $B_{12}$ ) with the administration of simvastatin, at a dose of $5 \mathrm{mg} / \mathrm{kg} /$ day i.p. (sim+mild Hhcy);

8. Animals fed with a diet enriched in methionine and deficient in $B$ vitamins (folic acid, $B_{6}$ and $B_{12}$ ) with the administration of atorvastatin, at a dose of $3 \mathrm{mg} / \mathrm{kg} /$ day i.p. (ato+severe Hhcy);

9. Animals fed with a diet enriched in methionine and deficient in $B$ vitamins (folic acid, $\mathrm{B}_{6}$ and $\mathrm{B}_{12}$ ) with the administration of simvastatin, at a dose of $5 \mathrm{mg} / \mathrm{kg} /$ day i.p. (sim + severe Hhcy).

\section{Determination of weight gain, food intake, and FER}

The starting date of the experiment was set as day "0," and the animals' body weights were measured every 24 hr. Body weight was measured until the final date of the experiment. The FER was obtained using the amount of food intake and the body weight increase during the entire experimental period; FER = increase of body weight (g)/ amount of food intake $(\mathrm{g})$ during the experiment.

\section{Determination of the biochemical parameters of hyperlipidaemia}

After a 4 week-dietary manipulation, the animals were sacrificed, and blood samples were collected by exsanguination. Prior to the blood collection, to measure the plasma parameters, the animals were fasted for $12 \mathrm{~h}$ in order to minimize the interference of food intake in the results of the lipid profile. In the serum samples, we determined the concentration of homocysteine and lipids, such as total cholesterol (TC), high-density lipoprotein cholesterol (HDL-C) and triglycerides (TG), low-density lipoproteincholesterol (LDL-C), and very low-density lipoproteincholesterol (VLDL-C). TC was measured by the method previously reported (17), and TG was measured by the colorimetric method previously reported (18). LDL-c was measured by the Friedewald formula (19). HDL-C and VLDL-C were determined using the method described by Zlatkis and Zak (20).

\section{Determination of the Atherogenic Index (AI) and the Cardiac Risk Ratio (CRR)}

The AI was calculated as LDL-C/HDL-C, and the CRR was calculated as (TC/HDL-C) (21).

\section{Liver histology}

For the histological examination, portions of the right and left liver lobes from each animal were fixed in $10 \%$ formalin and embedded in paraffin, a 7-micron thick section was stained with $\mathrm{H} \& \mathrm{E}$, and histological and morphometric analyses were performed. The liver histology was scored using a modification of the system developed by Brunt et al. (22). Briefly, the degree of steatosis, hepatocyte ballooning, lobular inflammation, and portal inflammation was scored separately in a blinded way. Each variable was graded from zero to three. The sum of the scores (degree of steatosis, hepatocyte ballooning, lobular inflammation, and portal inflammation) was considered the total pathology grade. The extent of steatosis was commonly evaluated and reported semi-quantitatively. The most reproducible method followed the acinar architecture dividing the liver parenchyma in thirds and assessing the percentage involvement by the steatotic hepatocytes as follows: 0\%-33\% (or $0 \%-5 \%, 5 \%-33 \%$ ) was considered mild, 33\%-66\% was considered moderate, and > 66\% was considered severe steatosis. The grading system for hepatic steatosis was as follows: grade 0 , no fat; grade 1 , steatosis affecting less than $33 \%$ of the hepatic parenchyma; grade 2 , steatosis affecting $34-66 \%$ of the hepatic parenchyma; and grade 3, steatosis affecting more than $66 \%$ of the hepatic parenchyma (23) (Table 1).

Table 1. Scoring system and total pathology grade of rat livers (degree of steatosis, hepatocyte ballooning, and lobular inflammation)

\begin{tabular}{|c|c|c|}
\hline Item & Definition & Score \\
\hline \multirow{4}{*}{ Steatosis } & $<5 \%$ (no fat) & 0 \\
\hline & 5-33\% (Grade 1) & 1 \\
\hline & $>33-66 \%$ (Grade 2) & 2 \\
\hline & $>66 \%($ Grade 3$)$ & 3 \\
\hline \multirow{4}{*}{$\begin{array}{l}\text { Lobular } \\
\text { Inflammation }\end{array}$} & No foci & 0 \\
\hline & $<2$ foci per $200 x$ field (Grade 1 ) & 1 \\
\hline & $2-4$ foci per $200 \times$ field (Grade 2 ) & 2 \\
\hline & $>4$ foci per $200 x$ field (Grade 3 ) & 3 \\
\hline \multirow{3}{*}{ Ballooning } & None & 0 \\
\hline & Few balloon cells & 1 \\
\hline & $\begin{array}{l}\text { Many cells/prominent } \\
\text { ballooning }\end{array}$ & 2 \\
\hline
\end{tabular}


Table 2. Effects of statins on the body weight gain, food intake, and FER values of rats with hyperhomocysteinemia (from a high-methionine diet after 4 wk)

\begin{tabular}{|c|c|c|c|c|c|}
\hline Groups & Initial weight (g) & Final weight (g) & Weight gain ${ }^{\mathrm{a}}(\mathrm{g})$ & Food intake (g) & FER $^{\mathbf{b}}$ \\
\hline Vehicle group & $96.00 \pm 9.06$ & $413.00 \pm 13.15^{*}$ & $317.00 \pm 11.01^{*}$ & $934.12 \pm 7.01 *$ & $0.34 \pm 0.01 *$ \\
\hline Mild HHcy & $104.63 \pm 6.96$ & $356.75 \pm 24.89^{*}$ & $252.12 \pm 9.02^{*}$ & $659.25 \pm 8.07 *$ & $0.38 \pm 0.02 *$ \\
\hline Severe HHcy & $105.88 \pm 6.66$ & $258.75 \pm 32.48$ & $152.87 \pm 8.24$ & $562.68 \pm 5.06$ & $0.27 \pm 0.01$ \\
\hline Atorvastatin per se & $104.02 \pm 5.55$ & $356.90 \pm 23.22 *$ & $255.88 \pm 10.11^{*}$ & $822.92 \pm 6.07^{*}$ & $0.31 \pm 0.01 *$ \\
\hline $\begin{array}{l}\text { Atorvastatin + mild } \\
\text { HHcy }\end{array}$ & $95.98 \pm 7.23$ & $277.33 \pm 24.22$ & $181.35 \pm 12.09$ & $687.41 \pm 4.05^{*}$ & $0.26 \pm 0.02$ \\
\hline $\begin{array}{l}\text { Atorvastatin }+ \text { severe } \\
\text { HНcy }\end{array}$ & $83.86 \pm 4.24$ & $259.30 \pm 31.23$ & $175.44 \pm 11.17$ & $494.85 \pm 4.08$ & $0.35 \pm 0.01 *$ \\
\hline Simvastatin per se & $100.14 \pm 3.58$ & $314.40 \pm 24.25^{*}$ & $214.26 \pm 14.12 \%$ & $781.64 \pm 9.04 \%$ & $0.27 \pm 0.02$ \\
\hline $\begin{array}{l}\text { Simvastatin + mild } \\
\text { HHcy }\end{array}$ & $93.13 \pm 5.55$ & $326.15 \pm 25.63^{*}$ & $233.02 \pm 13.13^{*}$ & $675.50 \pm 4.01 \%$ & $0.34 \pm 0.03 \%$ \\
\hline $\begin{array}{l}\text { Simvastatin + severe } \\
\text { HHcy }\end{array}$ & $91.38 \pm 4.98$ & $232.12 \pm 32.54$ & $140.74 \pm 11.12$ & $524.00 \pm 4.03$ & $0.27 \pm 0.01$ \\
\hline
\end{tabular}

aBody weight gain: final weight $(\mathrm{g})$ - initial weight $(\mathrm{g})$.

${ }^{\mathrm{b}}$ Feed efficiency ratio $($ FER) $=$ body weight gain $(\mathrm{g}) /$ food intake $(\mathrm{g})$.

\section{STATISTICAL ANALYSES}

The statistical analyses were performed using SPSS for windows version 22 . The results are presented as the mean \pm standard deviation (mean $\pm \mathrm{SD}$ ). Testing for significance was done using a Student's T-test and an analysis of variance (ANOVA), where applicable. Multiple comparisons of the mean differences among the variables were done using the Tukey post hoc test. P values less than or equal to 0.05 were considered significant.

\section{RESULTS}

\section{Homocysteine concentrations among the groups}

As we previously published (24), the rats fed with standard rodent chow had normal levels of Hcy $(<15 \mu \mathrm{M} / \mathrm{L})$, the rats fed with a methionine-enriched diet with $\mathrm{B}$ vitamins had mild elevated Hcy levels $(15-31 \mu \mathrm{M} / \mathrm{L})$, and the rats fed with a methionine-enriched diet that was deficient in B vitamins had extremely elevated Hcy levels $(>31 \mu \mathrm{M} / \mathrm{L})$.

\section{Weight gain, food intake and FER}

The initial weights of all the animals were similar and not statistically significantly different, but after four weeks of the dietary treatment, the final weights were significantly different among the groups. The weight gain and final weight were significantly higher in the groups fed with standard rodent chow (vehicle group, atorvastatin and simvastatin groups) and the groups fed methionineenriched food (mild Hhcy and simvastatin + mild Hhcy groups) than in the other groups (Table 2). The food intake was significantly higher in the groups fed the standard and methionine-enriched diets than in the groups fed the methionine-enriched and B-deficient diets. The FER was significantly higher in the mild-Hhcy group without statin administration and in the groups with statin treatment (atorvastatin, atorvastatin +severe Hhcy, simvastatin + mild Hhcy groups) than in all the other groups (Table 2).

\section{Lipid profile, Cardiac Risk Ratio (CRR) and Athero- genic Index (AI)}

The levels of all the lipoproteins were significantly different between the control groups. Tthe TC, TGs, LDL-C and VLDL-C levels were higher in the severe Hhcy and especially in the mild Hhcy groups than in the vehicle group (Table 3).

During the mild and severe Hhcy, atorvastatin at a dose of $3 \mathrm{mg} / \mathrm{kg} /$ day significantly reduced the levels of TC and the levels of TG, LDL-C and VLDL-C. On the other hand, the levels of all these lipoproteins were significantly higher after the atorvastatin administration in the group fed the standard food than in the vehicle group (Table 3). The concentration of HDL-C was not significantly changed (Table 3). The CRR and AI were significantly increased in the group fed standard food and were decreased in the groups with mild and severe Hhcy after the atorvastatin treatment (Table 3).

In the simvastatin + mild Hhcy and simvastatin + severe Hhcy groups, the levels of TC, TGs, LDL-C and VLDL-C were significantly decreased compared to those in the mild Hhcy and severe Hhcy groups, while in the simvastatin group, the values of TC, TGs, LDL-C and VLDL-C were significantly increased compared to those in the vehicle group (Table 4). The concentration of HDL-C was significantly affected only in the simvastatin group (decreased) (Table 4). The CRR and AI were significantly increased in the group fed standard food and were decreased in the groups with severe Hhcy after the simvastatin treatment (Table 3). 
Table 3- Effects of atorvastatin on serum TC (mg/dl), HDL-C (mg/dl), TGs (mg/dl), LDL-C (mg/dl) levels and atherogenic index of albino rats (Values are mean \pm SE from 8 animals in eacg group), P values: $<0.05$ when compared with "vehicle control, ${ }^{9}$ mild Hhcy, ${ }^{\S}$ severe Hhcy.

\begin{tabular}{|c|c|c|c|c|c|c|c|}
\hline Groups & TC & HDL-C & TGs & LDL-C & VLDL-C & $\begin{array}{c}\text { Cardiac Risk } \\
\text { Ratio } \\
\text { TC/HDL-C }\end{array}$ & $\begin{array}{c}\text { Atherogenic } \\
\text { Index } \\
\text { LDL-C/HDL-C }\end{array}$ \\
\hline Vehicle group & $101.94 \pm 3.77$ & $62.93 \pm 2.73$ & $59.29 \pm 1.12$ & $27.15 \pm 1.00$ & $26.95 \pm 0.09$ & $1.62 \pm 0.09$ & $0.43 \pm 0.06$ \\
\hline Mild HHcy & $221.62 \pm 4.85$ & $86.10 \pm 3.22$ & $108.85 \pm 4.37$ & $113.75 \pm 3.81$ & $49.48 \pm 1.25$ & $2.57 \pm 0.26$ & $1.32 \pm 0.13$ \\
\hline Severe HHcy & $148.26 \pm 2.85$ & $52.51 \pm 1.98$ & $99.12 \pm 3.85$ & $75.93 \pm 1.98$ & $45.05 \pm 1.34$ & $2.82 \pm 0.24$ & $1.45 \pm 0.15$ \\
\hline $\begin{array}{l}\text { Atorvastatin } \\
\text { per se }\end{array}$ & $128.18 \pm 3.21^{\circ}$ & $60.23 \pm 1.95$ & $86.73 \pm 1.98$ & $50.60 \pm 0.98$ & $39.42 \pm 1.11^{*}$ & $2.13 \pm 0.13^{*}$ & $0.84 \pm 0.08^{*}$ \\
\hline $\begin{array}{l}\text { Atorvastatin + } \\
\text { mild HHcy }\end{array}$ & $204.64 \pm 4.89$ & $93.82 \pm 2.55$ & $74.34 \pm 2.11^{9}$ & $95.95 \pm 2.54$ & $33.79 \pm 1.00$ & $2.18 \pm 0.16$ & $1.02 \pm 0.11^{9}$ \\
\hline $\begin{array}{l}\text { Atorvastatin + } \\
\text { severe HНcy }\end{array}$ & $103.48 \pm 2.11^{\S}$ & $47.49 \pm 1.53$ & $30.09 \pm 0.81^{\S}$ & $49.97 \pm 1.08^{\S}$ & $13.68 \pm 0.02^{\S}$ & $2.18 \pm 0.16^{\S}$ & $1.05 \pm 0.09 \S$ \\
\hline
\end{tabular}

\section{Hepatic histology}

The semi-quantitative histology results showed no visible lesions in the control group, whereas in the groups with mild and severe Hhcy, the liver sections showed areas of infiltration with lipid cells and degeneration of hepatocytes (Figure 1).

According to the different dietary treatments, fatty changes in the liver were distributed differently among the groups.

In the groups fed standard rodent chow and with normal levels of homocysteine, grade 1 fatty changes $(5-33 \%$ fat) were present in $70 \%$ of the animals, and grade 2 fatty changes (33-66\% fat) were present in $10 \%$ of the animals.

In the groups fed the methionine-enriched (mild Hhcy) diet, grade 3 (>66\% fat) steatosis was present in $100 \%$ of the animals.

In groups fed the methionine-enriched and B-deficient (severe Hhcy) diet, grade 1 steatosis (5-33\% fat) were present in $75 \%$ of the animals, grade 2 steatosis (33-66\% fat) was present in $12.5 \%$ of the animals, and grade 3 steatosis (>66\% fat) was present in $12.5 \%$ of the animals.

By the semi-quantitative measurements, the percent of lipid area was present as follows: the lipid field in the vehicle group was $0.14 \%$, in the atorvastatin group, it was
$2.9 \%$, and in the simvastatin group, it was $2.3 \%$. In the mild Hhcy group, the lipid field was $20.96 \%$, but in the ato+mild Hhcy group, it was lower, at $7.96 \%$; the lipid field was similarly lower in the sim+mild Hhcy group, at $8.68 \%$. In the severe Hhcy group, the lipid field was $36.32 \%$, but in the ato+severe Hhcy group, it was lower, at $31.11 \%$; the lipid field was similarly lower in the sim+severe Hhcy group, at $27.85 \%$ (Figure 2). The percent of lipid area in the ato and sim groups were significantly lower than those in the groups without drug treatment. Additionally, the percentage of fatty areas was significantly lower in the normohomocysteinaemic groups than in the hyperhomocysteinaemic groups (Figure 2).

\section{DISCUSSION}

Thirty years ago, the atherogenic properties of homocysteine were discovered by observation of arteriosclerosis in children with homocystinuria caused by aan inherited deficiency of three different enzymes (9-14). Hyperhomocysteinaemia is generally recognized as an independent risk factor for coronary, cerebral, and peripheral athero-

Table 4- Effects of simvastatin on serum TC (mg/dl), HDL-C (mg/dl), TGs (mg/dl), LDL-C (mg/dl) levels and atherogenic index of albino rats (Values are mean \pm SE from 8 animals in eacg group), P values: $<0.05$ when compared with "vehicle control, ${ }^{9}$ mild Hhcy, ${ }^{\$}$ severe Hhcy.

\begin{tabular}{|c|c|c|c|c|c|c|c|}
\hline Groups & TC & HDL-C & TGs & LDL-C & VLDL-C & $\begin{array}{c}\text { Cardiac Risk } \\
\text { Ratio } \\
\text { TC/HDL-C }\end{array}$ & $\begin{array}{c}\text { Atherogenic } \\
\text { Index } \\
\text { LDL-C/HDL-C }\end{array}$ \\
\hline Vehicle group & $101.94 \pm 3.77$ & $62.93 \pm 2.73$ & $59.29 \pm 1.12$ & $27.15 \pm 1.00$ & $26.95 \pm 0.09$ & $1.62 \pm 0.09$ & $0.43 \pm 0.06$ \\
\hline Mild HHcy & $221.62 \pm 4.85$ & $86.10 \pm 3.22$ & $108.85 \pm 4.37$ & $113.75 \pm 3.81$ & $49.48 \pm 1.25$ & $2.57 \pm 0.26$ & $1.32 \pm 0.13$ \\
\hline Severe HНcy & $148.26 \pm 2.85$ & $52.51 \pm 1.98$ & $99.12 \pm 3.85$ & $75.93 \pm 1.98$ & $45.05 \pm 1.34$ & $2.82 \pm 0.24$ & $1.45 \pm 0.15$ \\
\hline $\begin{array}{c}\text { Simvastatin } \\
\text { perse }\end{array}$ & $122.00 \pm 1.98^{*}$ & $46.72 \pm 2.11^{*}$ & $76.99 \pm 2.32^{*}$ & $59.88 \pm 2.05^{\prime \prime}$ & $35.00 \pm 1.32$ & $2.61 \pm 0.21^{*}$ & $1.28 \pm 0.11^{*}$ \\
\hline $\begin{array}{c}\text { Simvastatin + } \\
\text { mild HHcy }\end{array}$ & $172.20 \pm 2.14^{9}$ & $70.66 \pm 2.84$ & $38.94 \pm 0.09$ & $93.75 \pm 3.55^{9}$ & $17.70 \pm 0.07$ & $2.44 \pm 0.27$ & $1.33 \pm 0.15$ \\
\hline $\begin{array}{c}\text { Simvastatin + } \\
\text { severe HHcy }\end{array}$ & $142.86 \pm 1.57$ & $62.93 \pm 2.16$ & $79.65 \pm 2.15^{\S}$ & $64.00 \pm 1.78^{\S}$ & $36.20 \pm 1.21^{\S}$ & $2.27 \pm 0.32^{\S}$ & $1.02 \pm 0.09$ \\
\hline
\end{tabular}




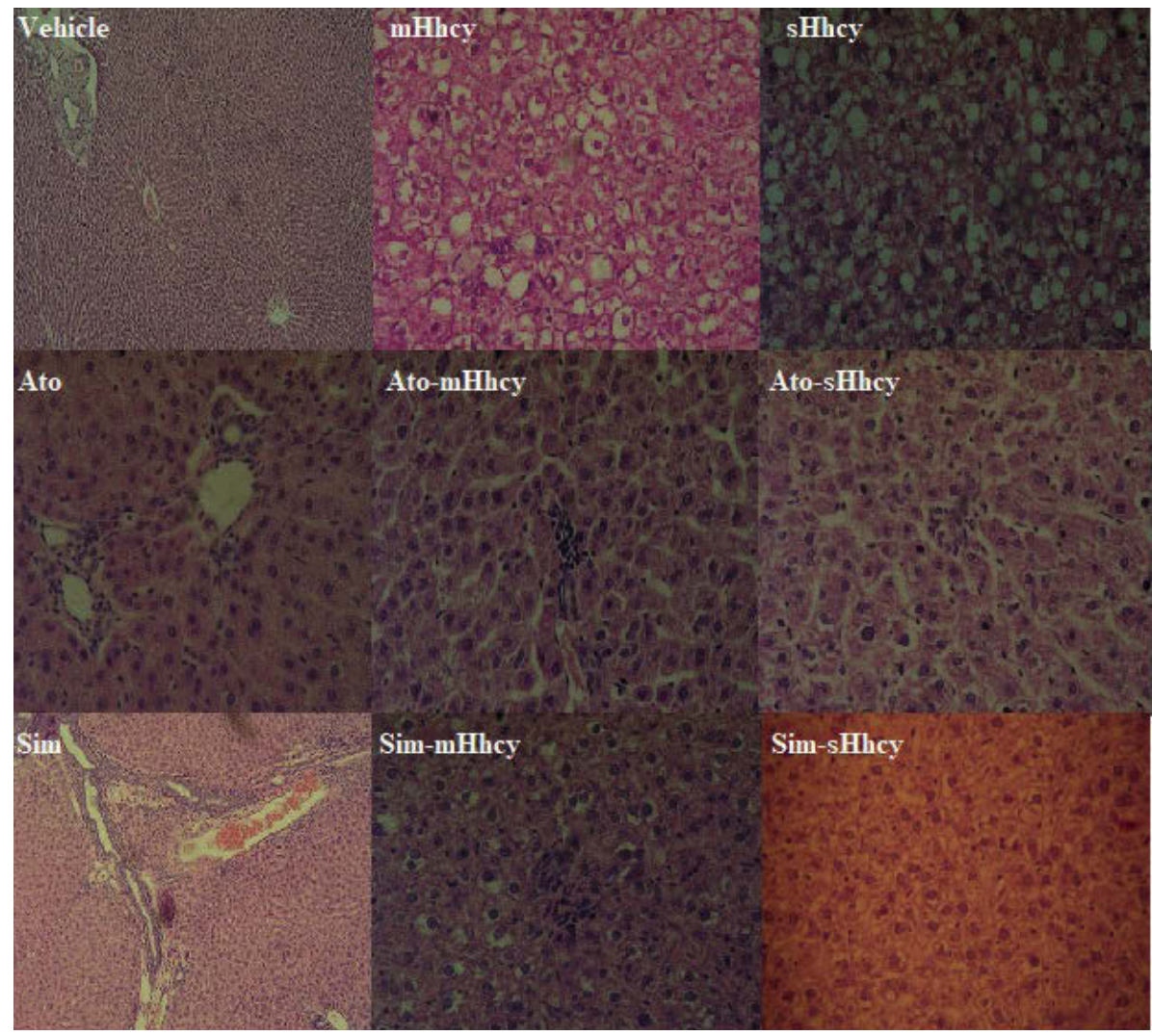

Figure 1. Histology results showing the effect of mild (mHhcy) or severe hyperhomocysteinaemia (sHhcy) and atorvastatin/simvastatin (ato/sim) on liver tissue. Representative haematoxylin-eosin (H\&E)-stained liver sections ( $\times 400$ and $\times 200$ objectives). After 4 weeks, feeding a methionine-purified diet induced mainly micr ovesicular steatosis, with a macrovesicular component. After 4 weeks of feeding a methionine-purified and B-deficient diet, the pattern of steatosis was macrovesicular and a scattered foci of inflammatory cells. In severe Hhcy, diffuse and extensive macrovesicular steatosis with foci of mononuclear inflammatory cells occurred. Compared to the groups without the statin treatment, extensive macrovesicular steatosis was reduced after the ato/sim treatment in states of mild and severe Hhcy.

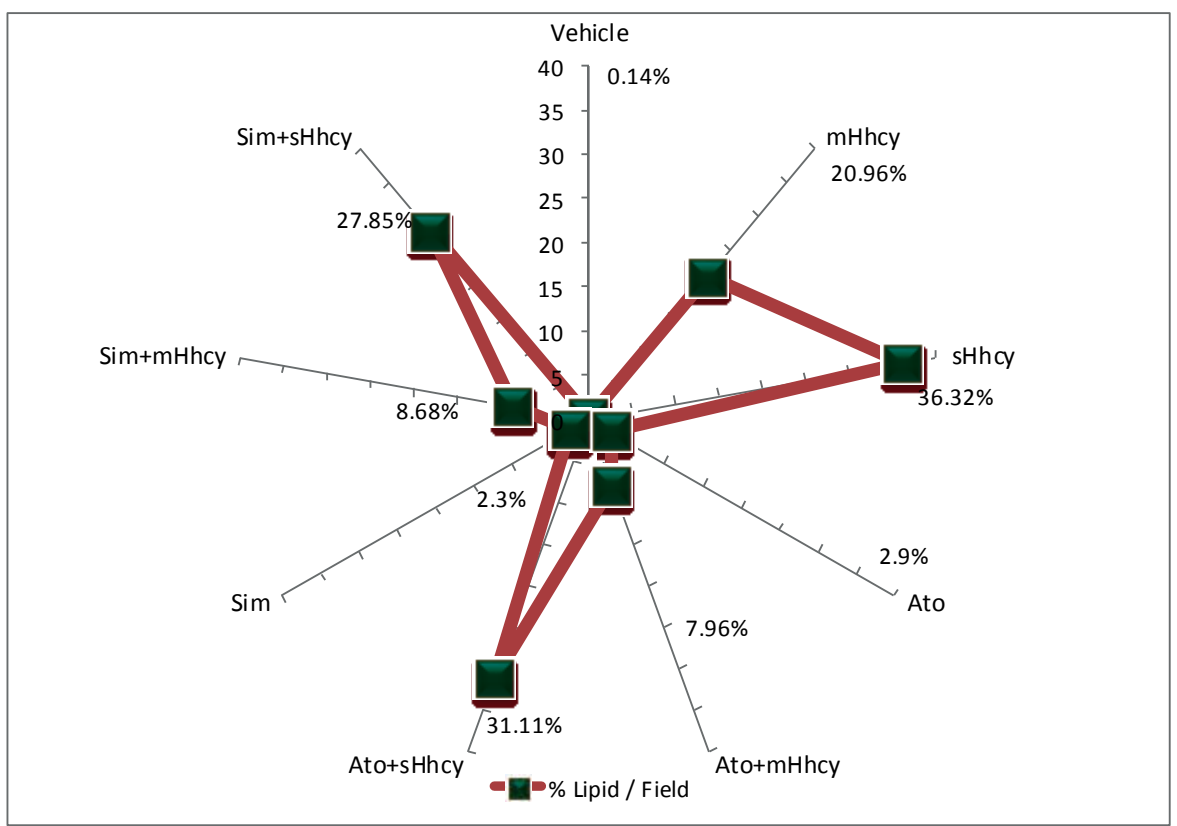

Figure 2. Distribution of fatty changes in the liver among all the groups. 
sclerosis (9) and numerous investigators report that elevated levels of tHcy, an amino acid formed during methionine metabolism, are related to CVDs. Elevated levels of tHcy are associated with an increased risk of atherothrombotic events, and the acute phase of myocardial infarction when there is an elevation of reactant proteins. Although the direction of the causality between elevated tHcy and CVD is not definitive, increasing clinical and epidemiological research supports the hypothesis that tHcy is an independent risk factor for CVD (9-15).

We hypothesized that Hcy has high atherogenic potential to induce dysregulation in the metabolism of lipoproteins in the liver, with the protective role of statins in this connection. In this study, we used two the most frequently used HMG-CoA reductase inhibitors, atorvastatin and simvastatin, at therapeutically equivalent doses. Additionally, we ascertained the utility of statins on the atherogenic index as an indicator and a significant adjunct for predicting atherosclerosis in hyperhomocysteinaemic male Wistar albino rats.

In the first part of the study, we evaluated the morphometric characteristics of the animals and the concentrations of the lipoproteins in the serum of the animals after four weeks of dietary and pharmacological treatment. Our results confirm elevated lipids (TC, Tgs, VLDL-C, LDL-C) in the hyperhomocysteinaemic rats compared to the rats with normal Hcy levels. The literature strongly suggests an association between Hcy and dyslipidaemia, and increased plasma Hcy leads to the formation of atheromatous changes, which ultimately cause myocardial infarction (MI) (11, 12). Potential mechanisms by which elevated Hcy induces increases in lipids may be in the structure of Hcy, which contains reactive a sulfhydryl group that undergoes oxidation to the disulfide at a physiological $\mathrm{pH}$. Therefore, upon oxidation, Hcy forms Hcy thiolactone. It is complexed with LDL-particles. This LDL-Hcy thiolactone complex aggregates and deposits in the form of thioco and then thioretinamide. These intermediates promote the proliferation and fibrosis of smooth muscles. During the conversion of thioco to thioretinamide, highly reactive oxygen species are generated, which cause several changes in the intima of the blood vessels and endothelial dysfunction and ultimately result in atherosclerotic plaques (9-15).

Furthermore, treatment with atorvastatin and simvastatin significantly reduces the elevated levels of lipids induced by hyperhomocysteinaemia. In comparison of these statins, simvastatin strongly reduced levels of TC, Tgs, VLDL-C and LDL-C compared to atorvastatin (Table 3 and 4). It is known that Hhcy increases the activity of HMG-CoA reductase, with an increased biosynthesis of cholesterol as a consequence. By blocking the conversion of HMG-CoA to L-mevalonate, statins decrease the levels of cholesterol $(13,14)$.

Additionally, protein targets for the modification by Hcy-thiolactone in human blood include fibrinogen, lowdensity lipoprotein, and high-density lipoprotein. At the same time, the primary target of the therapy is LDL-C. The latest LDL Guidelines (NCEP 2004 Update) suggest that levels higher than $70 \mathrm{mg} / \mathrm{dl}$ may be very high risk for CAD or as atherosclerotic levels of LDL-C (25). In the hyperhomocysteinaemic rats without statin treatment, we found high levels of LDL-C in mild and severe Hhcy, which were higher than $70 \mathrm{mg} / \mathrm{dl}$. According to the latest guidelines, this elevation of LDL-C indicates a very high risk for CAD. Treatment with statins, in our study, significantly decreased the levels of LDL-C in all the groups (Table 3 and 4).

A previous study suggested that decreased levels of HDL-C is one of the potential mechanisms of Hhcy-induced CVD. Additionally, statins might increase the levels of HDL-C and, by these alterations, achieve a protective role. Interestingly, in our study, the levels of HDL-C were not significantly altered. One of the possible explanations for this result is the very short time of Hhcy in vivo. According to King et al, only more than an 8-week duration of Hhcy is capable of decreasing the cardioprotective HDL-C fraction of lipoproteins, and different doses of statins differently affect the HDL-C concentration in various experimental models (26).

The atherogenic index indicates the deposition of foam cells or plaque or fatty infiltration or lipids in the heart, coronaries, aorta, liver and kidneys (5-11). The higher the AI is, the higher the risk of damage to the abovementioned organs. According to high levels of most of the measured lipoproteins in our study, the atherogenic index and cardiac risk ratio were similarly affected (Tables 3 and 4). In addition, the AI, calculated from the standard lipid profile, acts as an adjunct that significantly adds predictive value beyond that of the individual lipids and/or the TC/HDL-C and LDL/HDL$C$ ratios; in the present study, an increase in the AI and CRR were found, indicating atherosclerotic vascular damage (27).

In one of the few similar studies, Bhandari et al examined the ameliorative role of atorvastatin in methionineinduced Hhcy and haematological changes in albino rats. They used atorvastatin at a dose of $0.02 \mathrm{mg} / \mathrm{kg}$ bw per os for 30 days during a co-treatment with a high-methionine diet. They concluded that an oral treatment of atorvastatin significantly reduced the levels of Hcy, TC, TGs, LDL-C and VLDL-C, and increased the levels of HDL-C compared to the control group. These results are similar to ours, with differences in the dynamics of the levels of HDL-C, probably, because of the very different doses of atorvastatin $(0.02$ $\mathrm{mg} / \mathrm{kg} /$ day and $3 \mathrm{mg} / \mathrm{kg} /$ day) that were used (28).

Matte and colleagues evaluated the activities of aminotransferases in the liver and plasma of hyperhomocysteinaemic rats. Wistar rats received a daily subcutaneous injection of Hcy from their 6th to their 28th day of life. Twelve hours after the last injection, the rats were sacrificed, and the liver and plasma were collected. Hyperhomocysteinaemia decreased the antioxidant defences and total thiol content and increased the lipid peroxidation in the liver of the rats, characterising a reliable oxidative stress. The histological analysis indicated the presence of inflammatory infiltrate, fibrosis and a reduced content of glycogen/glycoprotein in the liver tissue sections from the 
hyperhomocysteinaemic rats. The aminotransferase activity was not altered by homocysteine. Their data showed a consistent profile of liver injury elicited by homocysteine, which contributed to explaining, at least in part, the mechanisms involved in human liver diseases associated with hyperhomocysteinaemia (29).

Zhang et al examined the influence of mild hyperhomocysteinaemia on the atherosclerotic inflammatory processes in rats. They concluded that elevated plasma homocysteine stimulates the activation of nuclear factor kappa B and, consequently, increases the expression of the inflammatory factors in vivo, which contribute to atherogenesis by enhancing the inflammatory response of the vascular endothelium (30).

Additionally, many other experimental studies also confirmed our results of the high atherogenic potential of Hcy and the protective role of atorvastatin and simvastatin in this connection $(31,32)$.

In a number of prospective clinical studies, in order to study the connection between homocysteine and lipid metabolism in atherosclerosis, homocysteine was determined in lipoprotein fractions in men with hypercholesterolaemia. All the lipoprotein fractions contained a considerably higher level of homocysteine in hypercholesterolaemia compared to normolipaemic men, varying from a 2.2 to 7.2 times higher estimated per unit volume of serum. The atherogenic index for cholesterol, the LDLChol/HDLChol, was 2.2 times higher in the hypercholesterolaemic group than in the normolipidaemic group. The results suggested that the analysis of the homocysteine content of the serum and lipoprotein fractions might prove to be useful for assessing the risk, prognosis and response to therapy in persons with atherosclerosis (33-35).

\section{CONCLUSION}

The connection between Hhcy and hyperlipidaemia, is indicated by our biochemical and histological analyses, makes Hhcy a pro-atherogenic state. The semi-quantitative histological measurements confirmed the negative effects of Hhcy in hepatic tissue and the protective effects of statins in Hhcy. The improvements in the lipid profile, along with the decrease in the atherogenic index by statins, might suggests that the antiatherogenic action of atorvastatin and simvastatin are in part dependent on their significant influence on homocysteine metabolism.

\section{FUNDING}

This work was supported by the Ministry of Education, Science and Technological Development of the Republic of Serbia (Grant No. 175043).

\section{CONFLICT OF INTEREST}

No conflicts of interest, financial, or otherwise, are declared by the authors.

\section{REFERENCES}

1. Brites FD, Bonavita CD, Cloes M, Yael M. VLDL Compositional changes and plasma levels of triglycerides and high density lipoproteins. Clinica Chimica Acta. 1998;269:107 124.

2. Goldberg DM. The Plasma Lipoprotein system. Clinical Biochemistry Reviews. 1981;2:341-353.

3. Burtis CA, Ashwood ER, editors. Tietz Fundamentals of Clinical Chemistry. 4th ed. Philadelphia, Pa: WB Sunders; 1996. Lipids, Apolipoproteins and Lipoproteins; pp. 375-386.

4. Cummings KC. Lipid and Cardiac Risk profiles. Clinical Chemistry. 2003;47:407-409.

5. Castelli WP. Cholesterol and lipids in the risk of coronary artery disease-the Framingham Heart study. Can J Cardiol. 1988;4:5-10

6. Hokanson JE, Austin MA. Plasma triglyceride level is a risk factor to cardio vascular disease independent of high density lipoprotein cholesterol level: a meta analysis of population based prospective studies. J Cardiovasc Risk. 1996;3:213-219.

7. Guerin M, Legoff W, Lassel TS, VanTol A, Steiner G, Chapman MJ. Proatherogenic role of elevated CE transfer from HDL to VLDL and dense LDL in type 2 diabetics. Arterioscler Thromb Vasc Biol. 2001;21:282-287.

8. Gaziano JM, Henne kens CH, O’Donnell CJ, Breslow JL, Buring JE. Fasting triglycerides, high density lipoprotein, and risk of myocardial infarction. Circulation. 1997;96:2520-2525.

9. Dobiasova M, Frohlich J. The plasma parameter log (TG/HDL-C) as an atherogenic index: correlation with lipoprotein particle size and esterification rate in apo B- lipoprotein-depleted plasma. (FERHDL) Clin Biochem. 2001;34:583-588.

10. Jakubowski H. Proofreading in vivo. Editing of homocysteine by aminoacyl-tRNA synthetases in Escherichia coli. J Biol Chem. 1995;270:17672-17673.

11. Jakubowski H. Metabolism of homocysteine thiolactone in human cell cultures. Possible mechanism for pathological consequences of elevated homocysteine levels. J Biol Chem. 1997;272:1935-1942.

12. Jakubowski H. Synthesis of homocysteine thiolactone in normal and malignant cells. In: Rosenberg IH, Graham I, Ueland PM, Refsum H, editors. Homocysteine metabolism: from basic science to clinical medicine. Norwell: Kluwer Academic Publishers; 1997. pp. 157-165.

13. Jakubowski H. Protein homocysteinylation: possible mechanism underlying pathological consequences of elevated homocysteine levels. Faseb J. 1999;13:2277-2283.

14. Jakubowski H. Calcium-dependent human serum homocysteine thiolactone hydrolase. A protective mechanism against protein N-homocysteinylation. J Biol Chem. 2000;275:3957-3962. doi: 10.1074/jbc.275.6.3957.

15. Jakubowski $\mathrm{H}$. The determination of homocysteinethiolactone in biological samples. Anal Biochem. 2002;308:112-119. doi: 10.1016/S0003-2697(02)00224-5. 
16. Eriksson M. [Statins have other beneficial properties besides their cholesterol lowering effect]. Lakartidningen. 1998 Aug 26;95(35):3670-2. Review. Swedish. PubMed PMID: 9748780

17. Demacher M, Hijamaus A. A study of the use of polyethylene glycol in estimating cholesterol. Clin Chem. 1980; $26: 1775$.

18. Foster L, Dunn R. Stable reagens for the determination os serum triglycerides by a colorimetric Hantzch condensation method. J Clin Chem 1973; 19:338.

19. Roberts WC. The Friedewald-Levy-Fredrickson formula for calculating low-density lipoprotein cholesterol, the basis for lipid-lowering therapy. Am J Cardiol. 1988;62:345-6.

20. Zlatkis A, Zak B, Boyle A. A new method for the direct determination of cholesterol. J lab Clin Med. 1953;41:486-486

21. Niroumand S, Khajedaluee M, Khadem-Rezaiyan M, et al. Atherogenic Index of Plasma (AIP): A marker of cardiovascular disease. Medical Journal of the Islamic Republic of Iran. 2015;29:240.

22. Brunt EM, Tiniakos DG. Alcoholic and nonalcoholic fatty liver disease. In: Odze RD, Goldblum JR, eds , editors. Surgical Pathology of the GI Tract, Liver, Biliary Tract and Pancreas. 2nd ed. Philadelphia: Elsevier; 2009. pp. 1007-1014

23. Kleiner DE, Brunt EM, Van Natta M, Behling C, Contos MJ, Cummings OW, Ferrell LD, Liu YC, Torbenson MS, Unalp-Arida A, et al. Design and validation of a histological scoring system for nonalcoholic fatty liver disease. Hepatology. 2005;41:1313-1321.

24. Nikolic T, Zivkovic V, Srejovic I, Stojic I, Jeremic N, Jeremic J, Radonjic K, Stankovic S, Obrenovic R, Djuric D, Jakovljevic V. Effects of atorvastatin and simvastatin on oxidative stress in diet-induced hyperhomocysteinemia in Wistar albino rats: a comparative study. Mol Cell Biochem. 2017 Jun 15. doi: 10.1007/s11010-017-3099-5.

25. Brown DJ. New guidelines for low-density lipoprotein levels fron the National Cholesterol Education Program (NCEP): a 2004 update.Prog Cardiovasc Nurs. 2004 Fall;19(4):165. PubMed PMID: 15539979.
26. King A. Cardioprotective effects of HDL cholesterol called into question. Nature Reviews Cardiology. 2012;9 [PubMed]

27. Rekhter MD. How to evaluate plaque vulnerability in animal models of atherosclerosis? Cardiovascular research. 2002;54:36-41.

28. Bhandari U, Pathan RA, Kumar V, Khanna N. Ameliorative role of atorvastatin on methionine-induced hyperhomcysteinemia and hematological changes in albino rats. Indian J Exp Biol. 2011: 132-9.

29. Matté C, Stefanello FM, Mackedanz V, Pederzolli CD, Lamers ML, Dutra-Filho CS, Dos Santos MF, Wyse AT. Homocysteine induces oxidative stress, inflammatory infiltration, fibrosis and reduces glycogen/glycoprotein content in liver of rats. Int J Dev Neurosci. 2009; 27(4):337-44. 7.

30. Zhang R, Ma J, Xia M, Zhu H, Ling WH. Mild hyperhomocysteinemia Induced by feeding Rats Diets Rich in Methionine or Deficient in Folate Promotes Early Atherosclerotic Inflamammatory Processes. J Nutr. 2004: 825-30.

31. Ankur Rohilla, M. U. Khan, Razia Khanam. Cardioprotective potential of simvastatin in the hyperhomocysteinemic rat heart. J Adv Pharm Technol Res. 2012; 3(3): 193-198.

32. Rohilla A, Ahmad A, Khan MU, Khanam R. A comparative study on the cardioprotective potential of atorvastatin and simvastatin in hyperhomocysteinemic rat hearts. Eur J Pharmacol. 2015;764:48-54.

33. Olszewski AJ, McCully KS. Homocysteine content of lipoproteins in hypercholesterolemia. Atherosclerosis. 1991 May;88(1):61-8. PubMed PMID: 1878010.

34. Malik J, Melenovsky V, Wichterle D et al. Both fenofibrate and atorvastatin improve vascular reactivity in combined hyperlipidemia (fenofibrate versus atorvastatin trial-FAT). Cardiovasc Res 2001: 290-8. 12.

35. Luftjohann D, Sigit IJ, Locatelli S, Bergmann VK. Highdose simvastatin $(80 \mathrm{mg} /$ day) decreases plasma concentrations of total homocysteine in patients with hypercholesterolemia. Atherosclerosis. 2001: 265-6. 
$\$$ sciendo 